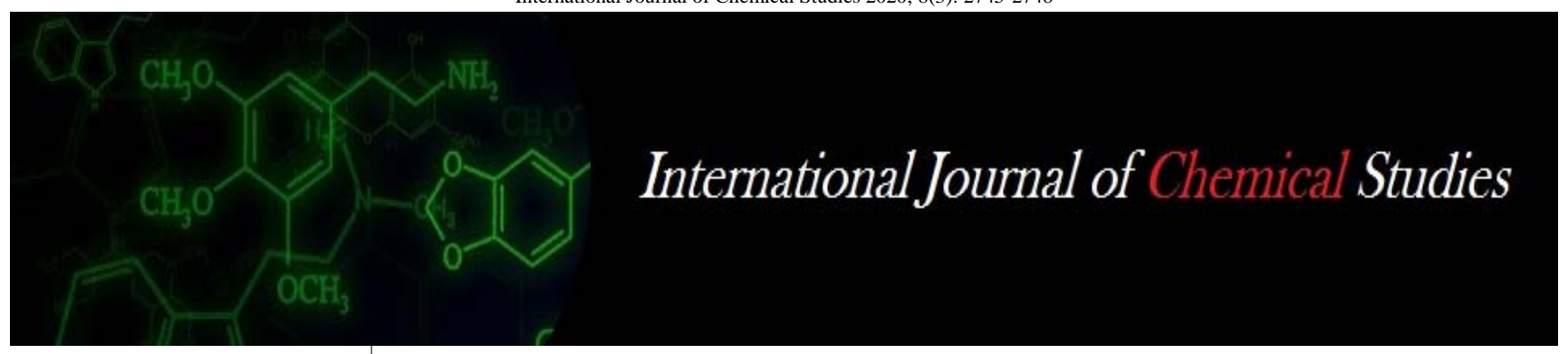

P-ISSN: 2349-8528 E-ISSN: 2321-4902 www.chemijournal.com IJCS 2020; 8(3): 2745-2748 (C) 2020 IJCS

Received: 21-03-2020 Accepted: 25-04-2020

Chetana Vasava

Department of Vegetable Science ASPEE College of Horticulture and Forestry Navsari

Agricultural University Navsari, Gujarat, India

Patel NK

Department of Vegetable Science ASPEE College of Horticulture and Forestry Navsari

Agricultural University Navsari, Gujarat, India

Himani Patel

Department of Vegetable Science ASPEE College of Horticulture and Forestry Navsari

Agricultural University Navsari, Gujarat, India

\section{Archana Mahida}

Department of Fruit Science ASPEE College of Horticulture and Forestry Navsari

Agricultural University Navsari, Gujarat, India

\section{Tandel BM}

Department of Fruit Science ASPEE College of Horticulture and Forestry Navsari

Agricultural University Navsari, Gujarat, India
Corresponding Author: Chetana Vasava Department of Vegetable Science ASPEE College of Horticulture and Forestry Navsari Agricultural University Navsari, Gujarat, India

\section{Effect of spacing and foliar spray of micronutrients on growth and yield of cluster bean (Cyamopsis tetragonoloba (L.) Taub.)}

\author{
Chetana Vasava, Patel NK, Himani Patel, Archana Mahida and Tandel \\ BM
}

DOI: $\underline{\text { https://doi.org/10.22271/chemi.2020.v8.i3am.9626 }}$

\section{Abstract}

An experiment was conducted, with a view to study the effect of spacing and foliar spray of micronutrient on growth and yield characters on cluster bean. Among levels of spacing, $\mathrm{S}_{3}(45 \mathrm{~cm} \times 30$ $\mathrm{cm}$ ) was found best in fresh weight, dry weight, number of clusters plant ${ }^{-1}$, number of pods cluster $^{-1}$, number of pods plant ${ }^{-1}$, total yield plant ${ }^{-1}$, pod yield ha ${ }^{-1}$. However, $S_{1}(45 \mathrm{~cm} \times 20 \mathrm{~cm})$ level of spacing gave maximum plant height and stem diameter. Foliar spray of $0.5 \% \mathrm{FeSO}_{4}+0.5 \% \mathrm{ZnSO}_{4}$ showed maximum stem diameter at 90 DAS, fresh weight of plant (148.64 g), number of clusters plant ${ }^{-1}$, number of pods cluster ${ }^{-1}$, number of pods plant ${ }^{-1}$, total pod yield plant ${ }^{-1}$, respectively. The treatment combination $\mathrm{S}_{3} \mathrm{~F}_{3}\left\{(45 \mathrm{~cm} \times 30 \mathrm{~cm})+\left(0.5 \% \mathrm{FeSO}_{4}+0.5 \% \mathrm{ZnSO}_{4}\right)\right\}$ showed significantly maximum number of pods plant $^{-1}$, pod yield plant ${ }^{-1}$ and hectare ${ }^{-1}$.

Keywords: Cluster bean, Growth Parameters, Yield Attributes, Spacing, $\mathrm{ZnSO}_{4}$ and $\mathrm{FeSO}_{4}$.

\section{Introduction}

Cluster bean [Cyamopsis tetragonoloba (L.) Taub.] is a diploid and popularly known as 'Guar' in India. It is one of the hardiest among all legume vegetables. The fleshy, long attractive, green, smooth tender pods with tender seeds rich in vitamin A and iron are consumed as vegetable. Vegetable legume crops require not only adequate macronutrients but also micronutrients for growth. Micronutrients are essential for the normal plant growth, deficiencies of which adversely affect the growth, metabolism and reproductive phase in plants. Zinc plays a vital role in the synthesis of chlorophyll, protein as well as nucleic acid. Zinc is the constituent of tryptophan which is a precursor of Auxin hormone. (Hafeez et al. 2013) ${ }^{[4]}$. Iron (Fe) play dominant role in oxidoredox reactions of photosynthesis and respiration. The deficiency of Fe in plants causes significant changes in plant metabolism and induce chlorosis, especially in young leaves and leads to very low reutilization. (Solanki et al. 2017) ${ }^{[15]}$. The plant to plant and row to row distance ensure proper utilization of different natural inputs. However, plants grown under optimum spacing had desirable population density per unit area which provides suitable conditions for crop growth and better plant canopy area due to maximum light interception, photosynthetic activity, assimilation and accumulation of more photosynthesis into plant system and hence they produce more seed yield with best quality traits (Mazumdar et al. 2007) ${ }^{[5]}$.

\section{Materials and Methods}

The field experiment was carried out at Vegetable Research Scheme, Regional Horticultural Research Station, Navsari Agricultural University, Navsari, Gujarat, India during Summer season of 2017-18 on cv. Pusa Navbahar to investigate the effect of spacing and foliar spray of micronutrients on growth and yield of cluster bean. The experiment was conducted in Randomized Block Design with Factorial concept (FRBD) which included two factor namely, Factor one is Spacing (S) viz., $\mathrm{S}_{1}-45 \mathrm{~cm} \times 20 \mathrm{~cm} ; \mathrm{S}_{2}-45 \mathrm{~cm} \times 25 \mathrm{~cm} ; \mathrm{S}_{3}-45 \mathrm{~cm} \times 30 \mathrm{~cm}$ and second factor is Foliar spray of micronutrients (F) $\mathrm{F}_{0}-$ Control (No spray); $\mathrm{F}_{1}-\mathrm{FeSO}_{4}$ $0.5 \% ; \mathrm{F}_{2}-\mathrm{ZnSO}_{4}-0.5 \% ; \mathrm{F}_{3}-\mathrm{FeSO}_{4} 0.5 \%+\mathrm{ZnSO}_{4} 0.5 \%$ and 12 treatment combination viz., $1 . \mathrm{S}_{1} \mathrm{~F}_{0}-(45 \mathrm{~cm} \times 20 \mathrm{~cm}+$ control $) ; 2 . \mathrm{S}_{1} \mathrm{~F}_{1}-\left(45 \mathrm{~cm} \times 20 \mathrm{~cm}+\mathrm{FeSO}_{4} 0.5 \%\right) ; 3 . \mathrm{S}_{1} \mathrm{~F}_{2}-(45 \mathrm{~cm} \times$ 
$\left.20 \mathrm{~cm}+\mathrm{ZnSO}_{4} 0.5 \%\right) ; 4 . \mathrm{S}_{1} \mathrm{~F}_{3}-\left[45 \mathrm{~cm} \times 20 \mathrm{~cm}+\left(\mathrm{FeSO}_{4} 0.5 \%\right.\right.$ $+\mathrm{ZnSO}_{4} 0.5 \%$ )]; 5. $\mathrm{S}_{2} \mathrm{~F}_{0}-\left[45 \mathrm{~cm} \times 25 \mathrm{~cm}+\right.$ control]; 6.S $\mathrm{S}_{2} \mathrm{~F}_{1}-$ [45 cm $\left.\times 25 \mathrm{~cm}+\mathrm{FeSO}_{4}-0.5 \%\right] ; 7 . \mathrm{S}_{2} \mathrm{~F}_{2}-[45 \mathrm{~cm} \times 25 \mathrm{~cm}+$ $\left.\mathrm{ZnSO}_{4}-0.5 \%\right] ; 8 . \mathrm{S}_{2} \mathrm{~F}_{3}-\left[45 \mathrm{~cm} \times 25 \mathrm{~cm}+\left(\mathrm{FeSO}_{4} 0.5 \%+\right.\right.$ $\mathrm{ZnSO}_{4}$ 0.5\% )]; 9. $\mathrm{S}_{3} \mathrm{~F}_{0}-\left[45 \mathrm{~cm} \times 30 \mathrm{~cm}+\right.$ control]; $10 . \mathrm{S}_{3} \mathrm{~F}_{1}-$ $\left[45 \mathrm{~cm} \times 30 \mathrm{~cm}+\mathrm{FeSO}_{4}-0.5 \%\right] ; 11 . \mathrm{S}_{3} \mathrm{~F}_{2}-[45 \mathrm{~cm} \times 30 \mathrm{~cm}+$ $\left.\mathrm{ZnSO}_{4}-0.5 \%\right] ; 12 . \mathrm{S}_{3} \mathrm{~F}_{3}-\left[45 \mathrm{~cm} \times 30 \mathrm{~cm}+\left(\mathrm{FeSO}_{4} 0.5 \%+\right.\right.$ $\mathrm{ZnSO}_{4}$ 0.5\%)]. The experiment included three replications. First foliar spray of micro nutrients was at 30 DAS and second at 45 DAS in early hours of morning.

The plant height was measured in centimeter with help of measuring tape from the ground level to top of the main shoot. The stem diameter was measured by Vernier caliperfrom the base of the primary leaf to base of hypocotyl and mean stem diameter was expressed in centimetre. For fresh weight plants fromeach treatment were uprooted carefully at the time of final harvesting and then fresh weight in gram per plant was recorded. For measurement of dry weight the plant was oven dried and then weight was measured with the help of weighing scale and noted. The number of clusters was counted on five plants and their average was expressed as number of clusters per plant. The number of pods borne on the individual cluster was counted from five tagged plants and the average was worked out and expressed as number of pods per cluster. The number of pods borne on individual plant was counted from plants and average was worked out, expressed as number of pods per plant. The pod yield at each picking was recorded and totalled worked out as pod yield per plant. The Pod yield per plot was multiplied with hectare conversion factor which expressed as pod yield ha ${ }^{-1}$ accordingly. The collected data were subjected to statistical analysis as per Panse and Sukhatme (1985) ${ }^{[8]}$.

\section{Results and Discussion}

The statistical comparison shows the significant influence of level spacing at 90 DAS, $\mathrm{S}_{1}$ exhibited maximum plant height of $106.57 \mathrm{~cm}$ which was at par with $\mathrm{S}_{2}$. This occurs because of less plant canopy area in which plant can grow more freely in vertical growth due to stiffer competition for space, light, nutrients, moisture etc. thus, consequently attained more plant height at narrow spacing. These results were in accordance with the findings of earlier workers viz., Chakravorty et al. (2009) ${ }^{[2]}$, Dev (2010) ${ }^{[3]}$ in French bean, Nandini et al. (2017) ${ }^{[7]}$ and Priyadarshini et al. (2017) ${ }^{[9]}$ in cluster bean.

In stem diameter, at 90 DAS $\mathrm{S}_{1}$ recorded the highest diameter of $1.60 \mathrm{~cm}$ which was at par with $S_{2}$ and $S_{3}$. This might be due to narrow spacing plants which intercepted more sunlight for photosynthesis as well as more nutrients for proper growth and development. These were in accordance with the findings of earlier workers viz., Dev (2010) [3] in French bean, Satodiya et al. (2015) ${ }^{[11]}$ and Priyadarshini et al. (2017) ${ }^{[9]}$ in cluster bean. Significantly maximum stem diameter of 1.78 $\mathrm{cm}$ was produced in $\mathrm{F}_{3}\left(0.5 \% \mathrm{FeSO}_{4}+0.5 \% \mathrm{ZnSO}_{4}\right)$ level of foliar spray of micronutrients. It might be due to iron with zinc sulphate foliar spray of micronutrients which helped to increase accumulation of carbohydrates in stem region leading to increased thickness. Analogous results regarding foliar spray of micronutrients were also reported by Selvaraj and Lakshmi prasana (2012) in cluster bean, Tak et al. (2014) ${ }^{[17]}$ in green gram and Sale et al. (2018) ${ }^{[10]}$ in cluster bean.

In respect to the fresh weight of plants $S_{3}(45 \mathrm{~cm} \times 30 \mathrm{~cm})$ level of spacing recorded significantly maximum fresh weight (151.23 g) at harvest. This might be due to plants grown with wider spacing got better opportunity of available maximum space, light and nutrients leading to maximum fresh weight per plant. The maximum weight of plant (148.64 g) was recorded with the application of micronutrients, $F_{3}(0.5 \%$ $\mathrm{FeSO}_{4}+0.5 \% \mathrm{ZnSO}_{4}$ ) which was at par with $\mathrm{F}_{2}$. Because zinc and iron sulphate foliar spray of micronutrients also helped to increase accumulation of carbohydrates in stem region leading to increased thickness. Analogous results regarding foliar spray of micronutrients were also reported by Selvaraj and Lakshmi prasana (2012) in cluster bean, Tak et al. (2014) ${ }^{[17]}$ in green gram and Sale et al. (2018) ${ }^{[10]}$ in cluster bean. Other hand, dry weight $\mathrm{S}_{3}(45 \mathrm{~cm} \times 30 \mathrm{~cm})$ produced maximum dry weight (18.42 g) which was at par with $\mathrm{S}_{2}$. It produced more photosynthates and maximum dry weight per plant which ultimately reflected in to better development of growth attributes with these treatments. These results were in accordance with the findings of earlier workers viz., Shrikanth (2008) in lablab bean, Satodiya et al. (2015) ${ }^{[11]}$ and Afifi et al. (2016) [1] in cowpea, Nandini et al. (2017) ${ }^{\text {[7] }}$ and Priyadarshini et al. (2017) ${ }^{[9]}$ in cluster bean.

In the spacing level of $\mathrm{S}_{3}(45 \mathrm{~cm} \times 30 \mathrm{~cm})$ recorded maximum number of clusters per plant (27.92), number of pods per cluster (6.96) and number of pods per plant(86.38) and it was at par with $\mathrm{S}_{2}$. These must be due to wider spacing had relatively less inter-plant competition because of more space availability to individual plants for reproductive growth. The findings of earlier workers Siddaraju (2010) ${ }^{[14]}$ and Nadini et al. (2017) in cluster bean. Foliar spray of micronutrients, $\mathrm{F}_{3}$ $\left.\left(0.5 \% \mathrm{FeSO}_{4}+0.5 \% \mathrm{ZnSO}_{4}\right)\right\}$ recorded significantly maximum number of clusters per plant (30.84), number of pods per cluster (6.58) and number of pods per plant (87.42). It might be due to reason that micronutrients provided a stimulus in the plant system, which in turn increased directly in various physiological processes and enzymatic activity for higher accumulation of food materials and Zinc was responsible for Auxin biosynthesis. The findings of earlier workers Mostafavi et al. (2012) ${ }^{[6]}$ and Afifi et al. (2016) ${ }^{[1]}$ in cow pea, Solanki et al. (2017) ${ }^{[15]}$, Sale et al. (2018) ${ }^{[10]}$ in cluster bean. The interaction effect $\mathrm{S}_{3} \mathrm{~F}_{3}\{(45 \mathrm{~cm} \times 30 \mathrm{~cm})+$ $\left.\left(0.5 \% \mathrm{FeSO}_{4}+0.5 \% \mathrm{ZnSO}_{4}\right)\right\}$ exhibited higher number of clusters per plant (34.73), number of pods per cluster (7.20) and number of pods per plant(123). The noticed influence might be due to better supply of

Table 1: Effect of spacing and foliar spray of micronutrients on plant height and stem diameter of cluster bean.

\begin{tabular}{|c|c|c|c|c|c|c|c|c|c|c|}
\hline \multirow{2}{*}{ Treatments } & \multicolumn{5}{|c|}{ Plant height (cm)at 90 DAS } & \multicolumn{5}{|c|}{ Stem diameter $(\mathrm{cm})$ at 90 DAS } \\
\hline & $\mathbf{F}_{\mathbf{0}}$ & $F_{1}$ & $\mathbf{F}_{2}$ & $\mathbf{F}_{3}$ & S Mean & $\mathbf{F}_{\mathbf{0}}$ & $\mathbf{F}_{1}$ & $\mathbf{F}_{2}$ & $F_{3}$ & S Mean \\
\hline $\mathbf{S}_{1}$ & 104.00 & 104.67 & 107.87 & 109.73 & 106.57 & 1.50 & 1.50 & 1.71 & 1.68 & 1.60 \\
\hline $\mathbf{S}_{2}$ & 104.06 & 103.06 & 102.80 & 106.80 & 104.18 & 1.44 & 1.57 & 1.50 & 1.79 & 1.57 \\
\hline $\mathrm{S}_{3}$ & 101.73 & 104.60 & 101.93 & 102.93 & 102.80 & 1.48 & 1.77 & 1.78 & 1.86 & 1.72 \\
\hline \multirow[t]{2}{*}{ F Mean } & 103.27 & 104.11 & 104.20 & 106.49 & & 1.47 & 1.61 & 1.66 & 1.78 & \\
\hline & \multicolumn{2}{|l|}{$\mathrm{S}$} & \multicolumn{2}{|l|}{$\mathbf{F}$} & $\mathbf{S} \times \mathbf{F}$ & \multicolumn{2}{|l|}{ S } & \multicolumn{2}{|l|}{$\mathbf{F}$} & $\mathbf{S} \times \mathbf{F}$ \\
\hline S. Em. \pm & \multicolumn{2}{|l|}{0.97} & \multicolumn{2}{|l|}{1.13} & 1.96 & \multicolumn{2}{|c|}{0.02} & \multicolumn{2}{|l|}{0.04} & 0.06 \\
\hline C.D.at 5\% & \multicolumn{2}{|l|}{2.87} & \multicolumn{2}{|l|}{ NS } & NS & \multicolumn{2}{|c|}{0.08} & \multicolumn{2}{|l|}{0.11} & NS \\
\hline C.V.\% & \multicolumn{5}{|c|}{3.24} & \multicolumn{5}{|c|}{7.21} \\
\hline
\end{tabular}


Table 2: Effect of spacing and foliar spray of micronutrients on fresh weight and dry weight of cluster bean plant

\begin{tabular}{|c|c|c|c|c|c|c|c|c|c|c|}
\hline \multirow{2}{*}{ Treatments } & \multicolumn{5}{|c|}{ Fresh weight at harvest (g) } & \multicolumn{5}{|c|}{ Dry weight at harvest (g) } \\
\hline & $F_{0}$ & $F_{1}$ & $\mathbf{F}_{2}$ & $\mathbf{F}_{3}$ & S Mean & $F_{0}$ & $F_{1}$ & $\mathbf{F}_{2}$ & $F_{3}$ & S Mean \\
\hline$S_{1}$ & 105.97 & 119.33 & 122.32 & 143.24 & 122.72 & 16.22 & 17.48 & 17.52 & 17.66 & 17.22 \\
\hline $\mathbf{S}_{2}$ & 109.92 & 138.76 & 139.49 & 139.64 & 131.95 & 16.92 & 17.68 & 17.84 & 18.89 & 17.83 \\
\hline $\mathrm{S}_{3}$ & 118.74 & 147.49 & 175.62 & 163.05 & 151.23 & 19.00 & 18.00 & 18.48 & 18.21 & 18.42 \\
\hline \multirow[t]{2}{*}{ F Mean } & 111.54 & 135.19 & 145.81 & 148.64 & & 17.38 & 17.72 & 17.95 & 18.25 & \\
\hline & \multicolumn{2}{|l|}{$\mathrm{S}$} & \multicolumn{2}{|l|}{$\mathbf{F}$} & $\mathbf{S} \times \mathbf{F}$ & \multicolumn{2}{|l|}{$\mathrm{S}$} & $\mathbf{F}$ & \multicolumn{2}{|c|}{$\mathbf{S} \times \mathbf{F}$} \\
\hline S. Em. \pm & \multicolumn{2}{|l|}{3.42} & \multicolumn{2}{|l|}{3.95} & 6.84 & \multirow{2}{*}{\multicolumn{2}{|c|}{\begin{tabular}{|l|}
0.24 \\
0.71 \\
\end{tabular}}} & .28 & \multicolumn{2}{|c|}{0.49} \\
\hline C.D.at 5\% & 10.02 & & 11.58 & & NS & & & NS & & \\
\hline C.V.\% & \multicolumn{5}{|c|}{8.75} & & & & & \\
\hline
\end{tabular}

Table 3: Effect of spacing and foliar spray of micronutrients on number of cluster per plant and number of pods per cluster of cluster bean.

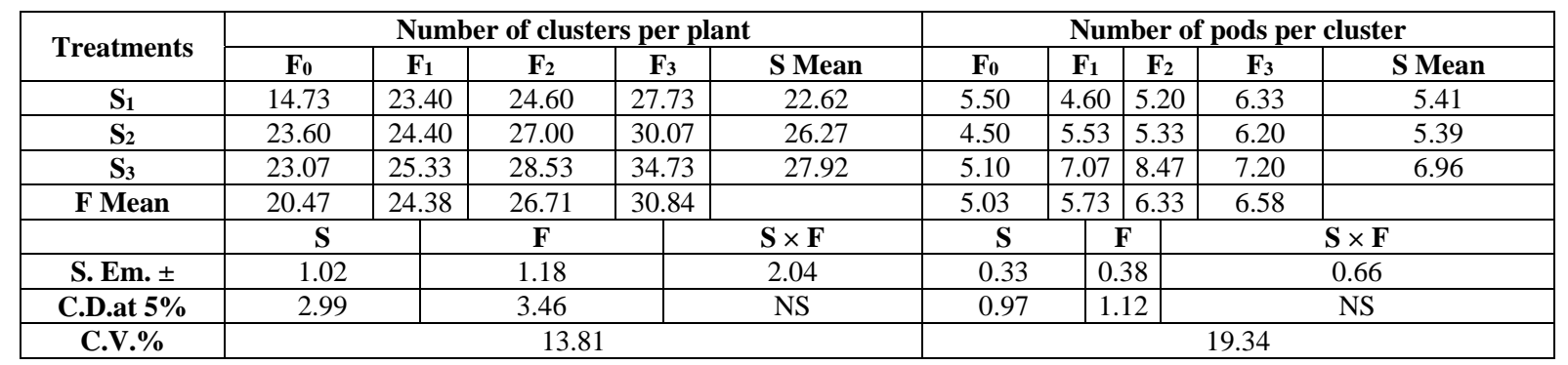

Table 4: Effect of spacing and foliar spray of micronutrients on number of pods per plant of cluster bean.

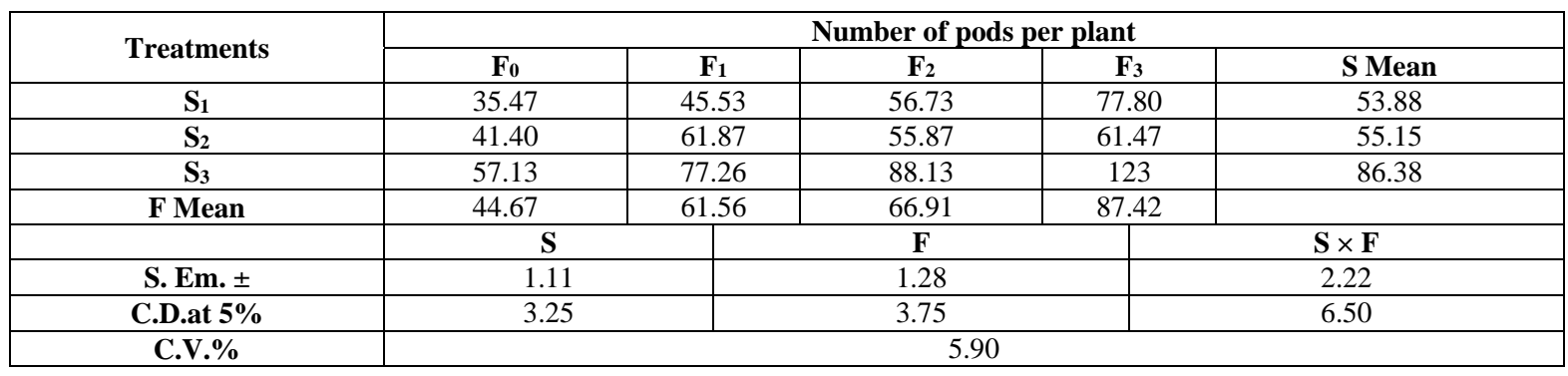

Table 5: Effect of spacing and foliar spray of micronutrients on pod yield per plant and pod yield per hectare of cluster bean.

\begin{tabular}{|c|c|c|c|c|c|c|c|c|c|c|}
\hline \multirow{2}{*}{ Treatments } & \multicolumn{5}{|c|}{ Pod yield per plant } & \multicolumn{5}{|c|}{ Pods yield per hectare } \\
\hline & $\mathbf{F}_{\mathbf{0}}$ & $F_{1}$ & $F_{2}$ & $F_{3}$ & S Mean & $F_{0}$ & $F_{1}$ & $F_{2}$ & $F_{3}$ & S Mean \\
\hline$S_{1}$ & 63.84 & 7.09 & 9.11 & 12.60 & 13.45 & 7.09 & 9.11 & 12.60 & 13.45 & 10.56 \\
\hline $\mathrm{S}_{2}$ & 85.68 & 7.62 & 10.15 & 8.66 & 9.71 & 7.62 & 10.15 & 8.66 & 9.71 & 9.03 \\
\hline $\mathrm{S}_{3}$ & 111.96 & 8.29 & 10.90 & 11.72 & 16.40 & 8.29 & 10.90 & 11.72 & 16.40 & 11.83 \\
\hline \multirow[t]{2}{*}{ F Mean } & 87.16 & 7.67 & 10.05 & 10.99 & 13.19 & 7.67 & 10.05 & 10.99 & 13.19 & \\
\hline & \multicolumn{2}{|l|}{$\mathrm{S}$} & \multicolumn{2}{|l|}{$\mathrm{S}$} & $\mathbf{F}$ & \multicolumn{2}{|l|}{$\mathrm{S}$} & \begin{tabular}{l|l|l} 
& 10.99 \\
& $\mathbf{F}$ & \\
\end{tabular} & \multicolumn{2}{|c|}{$\mathbf{S}$} \\
\hline S. Em. \pm & \multicolumn{2}{|l|}{4.62} & \multicolumn{2}{|l|}{0.48} & 0.55 & \multirow{2}{*}{\multicolumn{2}{|c|}{$\begin{array}{ll}0.48 \\
1.41\end{array}$}} & 0.55 & \multicolumn{2}{|c|}{0.48} \\
\hline C.D.at 5\% & \multicolumn{2}{|l|}{13.54} & \multicolumn{2}{|l|}{1.41} & 1.62 & & & & \multicolumn{2}{|c|}{1.41} \\
\hline C.V.\% & \multicolumn{5}{|c|}{13.46} & \multicolumn{2}{|l|}{1.41} & \multicolumn{3}{|c|}{15.85} \\
\hline
\end{tabular}

Nutrients along with conducive physical environment leading to better root activity and higher nutrient absorption, which resulted better yield attributes. This might be due to integrated use of zinc sulphate with iron sulphate fertilizers attributed to could have enhanced the plant nutrition which increases the assimilate production and balance of Auxin in plant also regulates the cluster drop in plants which ultimately increased the total number of pods per plant. The present findings on interaction effect are in agreement with those reported by Srivastava et al. (2017) ${ }^{[16]}$ in green gram.

The data of pod yield per plant and hectare among various levels of spacing, $\mathrm{S}_{3}(45 \mathrm{~cm} \times 30 \mathrm{~cm})$ noticed maximum pod yield per plant and hectare (16.40 g and $11.83 \mathrm{t}$ ). It occurs because spacing is responsible to less competition for space, moisture and nutrients which accelerated normal photosynthetic activity and more interception of photosynthetically active radiation. The present findings on spacing treatment are in agreement with those reported by Siddaraju
(2010) ${ }^{[14]}$ and Nadini et al. (2017) in cluster bean. In case of foliar spray of micronutrients levels, $\mathrm{F}_{3}\left(0.5 \% \mathrm{FeSO}_{4}+0.5 \%\right.$ $\mathrm{ZnSO}_{4}$ ) recorded significantly maximum pod yield per plant and hectare of (10.99 $\mathrm{g}$ and $13.19 \mathrm{t}$ ). An application of $\mathrm{Zn}$ and Fe were sprayed in combination involved directly in various physiological processes and enzymatic activity for higher accumulation of food materials and Zinc is responsible for Auxin biosynthesis. The balance of Auxin in plant also regulates the flower drop or retention in plants, which ultimately increased the total pods yield per plant and per hectare. Similar results on foliar spray of micronutrients were obtained by Mostafavi et al. (2012) ${ }^{[6]}$ and Afifi et al. (2015) in cow pea, Solanki et al. (2017) ${ }^{[15]}$, Sale et al. (2018) ${ }^{[10]}$ in cluster bean. The interaction effect $\mathrm{S}_{3} \mathrm{~F}_{3}\{(45 \mathrm{~cm} \times 30 \mathrm{~cm})+$ $\left.\left(0.5 \% \mathrm{FeSO}_{4}+0.5 \% \mathrm{ZnSO}_{4}\right)\right\}$ recorded maximum pod yield of $11.72 \mathrm{~g}$ per plant and $16.40 \mathrm{t}$ per hectare. These may be due to influence of spacing on developing pods which resulted in reduction in plant population per unit area under wider 
spacing and was able to compensate total yield, which further resulted in higher yield, increased pod yield per plant and per hectare production in wider spacing. Other hand fact that the balance of Auxin in plant also regulates the cluster drop in plants, which ultimately increased the total number of pods per plant noticed in combined zinc sulphate and iron sulphate. The present findings on interaction effect are in agreement with those reported by Srivastava et al. (2017) ${ }^{[16]}$ in green gram.

\section{Conclusions}

From this experiment and by considering the statistical analysis we can conclude that, in light of the results obtained in the present investigation, it inferred that growth and yield of cluster bean can be increased by interaction effect of spacing with foliar spray of micronutrients $\mathrm{S}_{3} \mathrm{~F}_{3}\{(45 \mathrm{~cm} \times 30$ $\left.\mathrm{cm})+\left(0.5 \% \mathrm{FeSO}_{4}+0.5 \% \mathrm{ZnSO}_{4}\right)\right\}$ followed by $\mathrm{S}_{1} \mathrm{~F}_{3}$.

\section{References}

1. Afifi ST, Zaghloul MM, Saady WA, Gammal RE. Effect of foliar application of iron on cluster bean [Cyamposis tetragonoloba (L.) Taub] varieties. J of Plant Production Mansoura Univ. 2016; 7(12):1245-1254.

2. Chakravorty S, Ghosh C, Mandal J. Effect of spacing on growth and yield of french bean (Phaseolus vulgaris L.) in red and lateritic belt of West Bengal. Environ. Ecology. 2009; 27(2):493-495.

3. Dev H. Standardization of planting time and spacing in french bean cv. Lakshmi as autumn crop for lower hills of Northern India. The Asian J Hortic. 2010; 5(2):318320.

4. Hafeez B, Khanif YM, Saleem M. Role of Zinc in Plant Nutrition- A Review. American J Experimental Agric. 2013; 3(2):374-391.

5. Mazumdar SN, Moninuzzaman M, Rahman SM, Basak NC. Influence of support systems and spacing on hyacinth bean production in the eastern hilly area of Bangladesh. Legume Research. 2007; 30(1):1-9.

6. Mostafavi K. Grain yield and yield components of soybean upon application of Different micronutrient foliar fertilizers at different growth Stages. International J Agric. Research and Review. 2012; 28(4):389-394.

7. Nandini KM, Sridhara S, Patil S, Kumar K. Effect of planting density and different genotypes on growth, yield and quality of guar. International $\mathrm{J}$ Pure and Applied Bioscience. 2017; 5(1):320-328.

8. Panse VG, Sukhatme PV. Statistical Methods for Agricultural Workers, Indian Council of Agricultural Research, New Delhi, India, 1985, 152-161.

9. Priyadarshini S, Rawat GS, Dwibedi SK. Effect of levels of primary plant nutrients and row spacing on growth and yield Attributes of Some Promising Varieties of cluster Bean (Cyamopsis tetragonoloba L.). International J Current Microbiology and Applied Science. 2017; 6 (12): 17-27.

10. Sale RB, Nazirkar RB, Thakare RS, Kondvilkar NB. Effect of foliar spray of zinc, iron and seed priming with molybdenum on growth and yield attributes and quality of soybean in the rainfed condition of Vertisol. International J Chemical Studies. 2018; 6(1):828-831.

11. Satodiya BN, Patel HC, Soni NV. Effect of planting density and integrated nutrient management on flowering, growth and yield of vegetable cowpea [Vigna unguiculata (L) Walp]. The Asian J Hortic.2015; 10(2):232-236.
12. Selvaraj S, Lakshmi Prasanna K. Dry matter production, yield attributes, yield and quality of cluster bean [Cyamopsis tetragonoloba (L.) Taub.]as influenced by nitrogen and zinc application. Indian J Plant Sci. 2012; 1(2-3):167-217.

13. Shrikanth. Effect of spacings and fertilizer levels on crop growth, seed yield and quality in Lablab bean (Lablab purpureus L.). Karnataka J Agric. Sci. 2008; 21(3):440443.

14. Siddaraju R, Narayanswami S, Ramegowda, Rajendra Prasad S. Studies on growth, seed yield attribute as influenced by varieties and row spacing in cluster bean. Mysore J Agric. Sci. 2010; 44(1):16-21.

15. Solanki RB, Yadav LR, Gupta A, Verma HP. Effect of foliar application of iron on cluster bean [Cyamposis tetragonoloba (L.) Taub] varieties. Research Environ. Life Sci. 2017; 10(4):295-298.

16. Srivastava N, Dawson J, Singh RK. Interaction effect of spacing, sources of nutrient and methods of zinc application on yield attributes and yields of green gram (Vigna radiata L.) in NEPZ. J Pharmacognosy Phytochemistry. 2017; 6(4):1741-1743.

17. Tak S, Sharma SK, Reagar ML. Effect of vermicompost and zinc on yield attributes, yield and quality of green gram [Vigna radiate (L.) Wilczek] in arid Rajasthan. International J Agric. Sci. 2014; 10(1):138-141. 